\title{
AN INTRODUCTION TO THE USE DF \\ PUBLICLY AVAILABLE INFORMATION IN ASSESSing AND MaNAGING Aboriginal RiskS
}

\section{A.W. (SANdy) Carpenter and Peter D. Feldberg ${ }^{\circ}$}

The authors examine differen strategies that oil and gas companies can use in assessing and managing the risks associated with the obligations on'ed to Canada's First Nations. The authors provide an introduction to the use of publicly available information that can assist in formulating risk strategies. Affer an overview of Treaty 8, the authors highligh information that is available with respect to certain First Nations in the Treaty 8 area.
Les auteurs examinen les differntes strategies que les pétrolières at gazières willsem pour évaher et gèrer les risques lids anx obligations envers fes Premières nations dit Canada. Les anteurs domon' une introduction sur l'utilisation de I'information accessible au public qui peul aider a formuler de telles stratégies. Après un aperçu du Traité 8. les aureurs soulignent l'information qui est accessible en ce qui concerne certaines Premieres nations relativement an Traité 8 .

\section{TABLE OF CONTENTS}

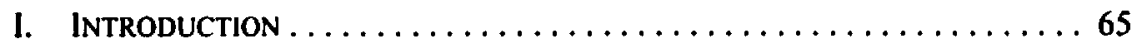

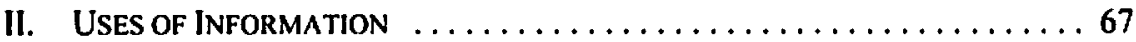

A. ABORIGINAL RISK ASSESSMENTS AND

MANAGING ABORIGINAL RISKS . .................67 67

B. CONSULTATION AND ACCOMMODATION ..............69 69

III. INDIVIDUAL FIRST NATION's RIGHTS UNDER TREATY $8 \ldots \ldots \ldots \ldots \ldots 7$ I

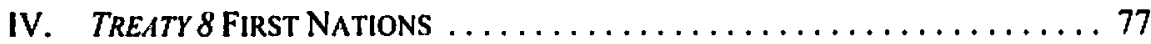

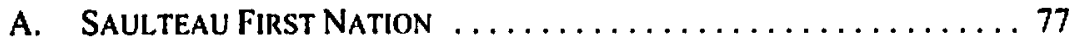

B. The Dene Tha' First Nation $\ldots \ldots \ldots \ldots \ldots \ldots \ldots \ldots \ldots . \ldots \ldots$

C. Mikisew CReE First Nations AND

athabasca ChIpewyan First Nations $\ldots \ldots \ldots \ldots \ldots \ldots \ldots .68$

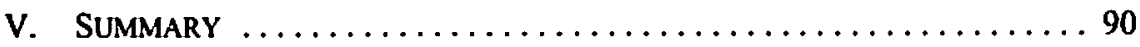

\section{INTRODUCTION}

Over the past 15 years, the risk that a government may fail to meet its obligations to First Nations with respect to exploration and development activities has become a significant risk for oil and gas companies operating in areas where treaty or Aboriginal rights exist or may exist.' As oil and gas activities move into more remote areas where the exercise of treaty or

- This article was prepared for presentation at the 2005 Canadian Petroleum Law Foundation Research Seminar. The authors are both parners in the Calgary office of Fasken Martineau DuMoulin LLP, and practice generally in the areas of Aboriginal and regulatory law. The authors also wish to thank Linda Huynh, an associate in the Calgary office, for her assistance with the preparation of this article.

This article does not attempt to provide a detailed review of the law regarding governments' obligations to First Nations. For an overvieu of this issue, see Tony Fogarassy \& KayLynn Litton. "Consultation with Aboriginal Peoples: Impacts on the Petroleum Industry" (2004) 42 Alta. L. Rev. 41, which was presented at the 2003 Canadian Petroleum Law Foundation Research Seminar. An analysis of the law in this respect cannot be complete without consideration of Haida Nation v. British Columbia (Minister of Forests), [2004] 3 S.C.R. SI1, 2004 SCC 73 [Haida] and Mikisew Cree First Nation v. Canada (Minister of Canadian Heritage), [2004] 3 F.C.R. 436, 2004 FCA 66 [Mfikisew] which, at the time of writing had been heard by the Supreme Court of Canada, and judgment reserved (now reported at [2005] 3 S.C.R. 388, 2005 SCC 69). 
Aboriginal rights continues to be a significant form of land use, the likelihood of encountering Aboriginal issues and the risk associated with these issues increases. Given that the cost of conducting operations in remote areas is generally significantly higher, and timing considerations are often more critical than conducting oil and gas activities in more conventional locations, the consequences of such a failure by government to satisfy its obligations to First Nations will also tend to be more severe.

Coincidentally, with the expansion of oil and gas activity into new areas, a number of recent decisions ${ }^{2}$ have: (i) expanded or clarified the scope of government action that may give rise to a duty to First Nations (including government decisions at the "strategic planning" level); (ii) more clearly defined the nature of governments' obligations to consult with and, if necessary, accommodate the interests of First Nations; and (iii) more clearly defined the nature of the obligation of First Nations to participate in that process. If a court finds that government has failed to satisfy its obligations, often the remedy is to set aside the permit or authorization in question. ${ }^{3}$ These factors, and others, ${ }^{4}$ have generally caused industry to become more aware of Aboriginal issues and, in many cases, to be more proactive in attempting to manage the risks associated with these issues.

Reconciliation of modem resource development with the continued exercise of Aboriginal and treaty rights, regardless of the legal tests used to define those rights or the precise formulation of the government's duties to protect them, is most often practically achieved, on a project-by-project basis, by assessing the potential impacts of a proposed development on the site-specific exercise of treaty or Aboriginal rights. The case law is clear that in any consultative process, it is up to the First Nation to provide the evidence necessary to assess the nature of the right that may be affected and the scope of its exercise. This makes sense, as it is only the First Nation that knows how and where its members carry on traditional activities and exercise their treaty or Aboriginal rights. But such consultation typically occurs with respect to resource development projects only after a resource developer is in a position where it is ready to make its intentions or plans known. A question that often arises is how, prior to engaging in a formal consultation process, a project developer can make an initial assessment of the Aboriginal risks of the potential development?

There is a variety of publicly available material about many Aboriginal groups and their rights. There are, of course, traditional primary and secondary sources that can be reviewed by researchers to provide an historical and ethnographic assessment of a particular Aboriginal group. In addition, many First Nations have their own websites. These websites often provide demographic information, historical overviews, information on governance

Sec e.g., Haida, ibid.

See e.g. Halfway River First Nation v. British Columbia (Ministry of Forests)(1997), 39 B.C.L.R. (3d) 227 (S.C.), afTd (1999), 64 B.C.L.R. (3d) 206, 1999 BCCA 470 (quashing of cutting permit) [Halfivay River): Mikisew Cree Firsı Nation v. Canada (Minisser of Canadian fleritage) (2001), 214 F.T.R. 48. 2001 FCT 1426 [Mikisen 200/], rev'd by Mikisew (C. A.), supra note 1 (quashing of road construction permit); Taku River Tlinget First Nation v. British Columbia (Project Assessmem Director) (2000), 77 B.C.L.R. (3d) 310, 2000 BCSC 1001, aff d (2002), 98 B.C.L.R. (3d) 16, 2002 BCCA 59, rev'd [2004] 3 S.C.R. 550, 2004 SCC 74 (quashing of project approval certificate) [Tuku River].

In addition to obligations imposed by the courts, governments have also developed policies to reconcile resource exploration with Aboriginal and treaty rights, placing significant obligations on industry in the process. 
structures, discussions on topics of interest, and contact information. Similarly, Indian and Northern Affairs Canada's website provides First Nation profiles including, in some cases, linkages to other sources of information. ${ }^{5}$ However, often the most probative materials are those that have been generated as part of the recent emergence of Aboriginal issues. In many cases, First Nations have engaged in previous litigation to attempt to establish rights or challenge government authorizations. In other cases, First Nations have participated in public processes or hearings. Finally, many First Nations have undertaken and completed traditional use studies. These initiatives have resulted in pleadings, affidavit materials and other sworn testimony, and detailed studies that describe traditional and current Aboriginal practices, outline traditional territories and sensitive areas and, in some cases, provide useful information regarding the site-specific exercise of Aboriginal or treaty rights.

Notwithstanding industry's increased awareness of Aboriginal issues and the availability of materials, in many cases, resource developers do not use publicly available information to help assess Aboriginal risks or make certain that they are prepared to fulfil their role in ensuring that the government satisfies its obligations to First Nations. This article provides an introduction to the use of publicly available information in assessing the Aboriginal risks associated with a project or program and, potentially, in managing these risks (Part II). ${ }^{6}$ It then highlights this discussion in one area of significant industry interest, the Treaty 8 area, by first providing an overview of Treaty 8 , including a discussion of individual First Nation's potentially different rights under Treaty 8 (Part III), and providing some illustrative examples of what may be found with reference 10 a few of the First Nations in the Treaty 8 area (Part IV). The article then concludes with a general summary (Part V).

\section{USES OF INFORMATION}

\section{A. Aboriginal Risk ASSESSMents and MANaging Aboriginal Risks}

It has now been determined that "third parties" do not have a common law duty to consult and accommodate First Nations, and that the ultimate responsibility for fulfilling this duty lies with the Crown. ${ }^{8}$ However, as indicated, industry should still be vitally interested in whether the Crown is fulfilling its responsibilities since it is often industries' permits and authorizations that are at risk of being set aside if the Crown fails to satisfy those obligations. Further, while the ultimate responsibility for consultation and accommodation rests with the

s See First Nation Protiles, online: Indian and Northern Affairs Canada <http://sdiprod2.inac. ge.ca/FNProfiles/>.

- While the article does not discuss in detail how to locate publicly available materials, in most cases this is self-evident given the nature ol' the matcrials discussed.

- Canada, Treayy No. 8 Made Jume 21. 1899 and Adhesions, Reports. Etc. (Ottawa: Queen's Printer, 1966) [Treab' 8 ]. See an online version of Treaty 8 at Indian and Northem Aflairs Canada, online: <w ww aincinac.ge.ca/pr/trts/trty8_e.html>. Treaty 8 was chosen because it provides the broadest applicalion and. as mentioned, is an area of significant industry interest. Treaty 8 covers areas of northeast BC. northern Alberta, northeast Saskatchewan, and the southem Northwest Territories. There are both treaty and nontreaty First Nations in this area. Finally, Trean' 8 includes areas that incorporale conventional, fronticr, and oilsands production.

s Haida, supra note 1 at paras. 52-53. 
Crown, the Crown "may delegate the procedural aspects of consultation to industry proponents seeking a particular development."

Regardless of whether a company may become directly involved in attempting to resolve Aboriginal issues associated with a given proposal, it is often useful to conduct an Aboriginal risk assessment prior to entering a new area or seeking approval to undertake a significant project or program in an existing operating area. The results of such a risk assessment may cause a company to reconsider investing in a given area, or help inform an Aboriginal risk management strategy.

A full discussion of how to undertake an Aboriginal risk assessment or how to put in place an Aboriginal risk management strategy is beyond the scope of this article. In general terms, an Aboriginal risk assessment applies existing information to the relevant Aboriginal legal framework to identify potential risks, in an Aboriginal law context, of undertaking a particular project or program. It involves an assessment of the First Nations that may be affected by a particular project, an assessment of the rights of these First Nations, and an initial assessment of the potential impacts of a project on the exercise of those rights. It is generally used to provide a resource developer with an initial assessment of the risk of proceeding with a project prior to public disclosure of the project developer's intentions. Publicly available information with respect to an Aboriginal group, its traditional territory, the exercise of its rights, site-specific issues, and other matters all form an input into this analysis.

Aboriginal risk assessments can be performed more than once during the development stage of a major project or program. However, to maximize the usefulness of such an assessment, it is usually advisable to conduct such an assessment as early in the planning stages of a project as possible. Knowledge of the existence of Aboriginal peoples and their asserted or proven rights is the starting point for applying the first stage of the legal analysis established in Sparrow ${ }^{10}$ and Haida. As McLachlin C.J.C. stated in Haida:

Bul, when precisely does a duty to consult arise? The foundation of the duly in the Crown's honour and the goal of reconciliation suggest that the duty arises when the Crown has knowledge, real or constnuctive, of the potential existence of the Aboriginal right or title and contemplates conduct that might adversely affect it."

Traditionally, courts have treated First Nations' claims that governments have not satisfied their obligations to them as discrete questions to be determined in isolation from their other dealings with government, and have held that as the first stage of the analysis, the onus of proving that there is an Aboriginal or treaty right at issue is on the First Nation challenging

- Hid. at para. 53. The authors acknowledge that Haida delines the legal tests applicable to consultation and accommodation ubligations in the context of asserted, but unproven Aboriginal rights. The corresponding legal tests with respect to project development in areas subject to the numbered treaties remains to be defined with the same clarity. That clarity may be achicved upon release of the Supreme Court of Canada's judgment in Mikisew, supra note 1. 
the action. ${ }^{12}$ While First Nations still have this burden, the courts increasingly rely on extrinsic evidence from other interactions between the Crown and First Nations to provide both the knowledge required to trigger the duty, and some evidence of the scope and content of the duty itself. ${ }^{13}$ Publicly available information with respect to the potential existence of the Aboriginal or treaty right, and the exercise of that right in the area in question (particularly when it is clear that this information has been made available to government) can be significant in determining when this duty is triggered. In Taku River, for example, the Supreme Court of Canada referred to the Province of British Columbia's knowledge and acceptance of the Taku River Tlingit's claim under the treaty process in British Columbia as evidence that would support the necessary finding that the Province had knowledge of the rights and title claim of that First Nation. It may not be inconceivable that a court could find that constructive knowledge of a claim, or the site-specific exercise of treaty or Aboriginal rights, may similarly be based on evidence filed in other proceedings.

Accordingly, companies who formerly relied, perhaps inappropriately, ${ }^{14}$ on the fact that a First Nation had not raised its rights with government as some protection against a subsequent claim that its rights had been infringed, may now wish to consider information with respect to a First Nation's rights that has been made available through other interactions with government. If it is clear that information is available to government that would likely trigger this aspect of the legal test, and government has not taken or is unlikely to take the necessary steps to consult with the First Nation in question, steps may be required under an Aboriginal risk management strategy to attempt to mitigate this risk. The earlier a risk assessment takes place, the greater the likelihood that these steps will be successful. An Aboriginal risk assessment early in the planning stages of a project can also influence project design and, as mentioned, may even affect whether the project is pursued.

An Aboriginal risk assessment that takes place early in the planning stages of a project or program will usually have to rely on publicly available information. As project planning and, where appropriate, consultation progress, this information can be supplemented or replaced by information provided directly by the First Nation(s) in question.

\section{B. Consultation and ACCOMmodation}

The essence of the duty to consult with First Nations and, if necessary, to accommodate their interests, is rooted in the "goal of reconciliation," the dominant theme of Aboriginal law in the past several years. At its heart, consultation involves an information exchange with respect to the nature and potential impact of a given activity, and an assessment of the Aboriginal or treaty rights that may be affected by that activity. Reconciliation, where there

Sparrow, supra nole 10 at 1112.

Sec Haida Nation v. British Columbia (Minister of Fores/s) (2002), 99 B.C.L.R. (3d) 209, 2002 BCCA 147, with supplementary reasons at (2002), 5 B.C.L.R. (4th) 33, 2002 BCCA 462; Taku River, supra note 3; Hutt-Ay-Ahi First Nation v. British Columbia (Minister of Forests) (2005), 33 Admin. L.R. (4th) 123,2005 BCSC 697.

Note that even under a traditional Sparrow analysis, there is a positive obligation on the government to ensure that the First Nation(s) in question is aware of a proposed activity, and is in a position to determine if their rights will be affected by that activity: $R$. $v$. Sampson (1995), I6 B.C.L.R. (3d) 226 (C.A.) at para. 109. 
is a conflict, is achieved through various forms of accommodation that may range from changes to a project to avoid or minimize interference with the exercise of Aboriginal or treaty rights, to compensation where the conflict cannot otherwise be resolved.

Achieving reconciliation in this context requires an information exchange on both sides of the equation. The courts have been very clear that consultation is a "two-way" street. A number of cases have illustrated that failure to provide a First Nation with relevant information will not satisfy the obligation. A number of cases have also made clear that "site specific evidence" with respect to the exercise of a right will be required from the First Nation, and that broad and vague assertions of rights that may be infringed are not acceptable. ${ }^{\text {is }}$

As indicated, it has now been established that industry does not have an independent duty to consult and accommodate First Nations. ${ }^{16}$ However, in many cases, industry will be delegated certain procedural aspects of this duty while government retains the ultimate responsibility for ensuring the duty is carried out. ${ }^{17}$

In the event that industry is delegated the responsibility for carrying out the procedural aspects of consultation, or is undertaking its own efforts as part of a risk management strategy, public information can also play a significant role in the consultation, and if necessary, accommodation process. This includes:

(i) providing a starting point for identifying those First Nations who may potentially be affected by a particular activity;

(ii) providing an introduction to the First Nation(s) in question, including some understanding of their history, governance structure, and current issues of concern;

(iii) providing information on the nature of the rights in question;

(iv) providing information on preferred areas of exercising those rights;

(v) providing information on other areas of special importance; and

(vi) in some cases, providing actual site specific information.

While neither the Crown nor industry can rely solely on publicly available information to fulfil the Crown's obligations to First Nations, this information can inform the consultation process and, as mentioned, may even be of direct legal relevance in determining the scope of the duty itsclf. In addition, as highlighted below, publicly available information can

15. See e.g., /lalfway River (C.A.), supra note 3 at para. 211; /Naida, supra note I at paras. 36, 42; and Heillsuk Tribal Council v. British Columbia (Minister of Sustainable Resource Management) (2003), 19 B.C.L.R. (4th) 107, 2003 BCSC 1422.

Haida, ibid.

Haida, ibid. at para. 53. See also, ce.g. Alberta, Aboriginal Afrairs and Northem Development (AAND), The Govermment of Alberta's First Nations Consultation Policy on Land Management and Resource Development (16 May 2005), online: AAND <www.asand.gov.ab.ca/ANNDFlash/Files/Policy_ Approved___May_16.pdib at 30:

2. Alberta is responsible for managing the consultation process.

4. Whilu each has very diflerent roles, the consultation process requires the participation of First Nations, the Project Proponen and Alberta [emphasis in original].

See also the "Project-Specilic Consultation" and "Alberta"s Expectations of Industry" sections at 5-6. 
provide an indication of the type of information that is readily available to the First Nation in question and that, theoretically, should be shared as part of the consultation and accommodation process.

\section{INDIVIDUAL FIRST NATION'S RIGHTS UNDER TREATY \&}

The starting point for any assessment of the rights of First Nations within the area covered by Treaty $8^{18}$ is, of course, the treaty itself. The area covered by Treaty' 8 is shown below and extends across portions of northern Saskatchewan, Alberta, British Columbia, and into the Northwest Territories." ${ }^{19}$ The Treaty was signed by various groups of Cree, Beaver, Chipewyan, and other Indians in the summer of 1899. A number of adhesions followed in 1900 , with further adhesions at later dates.

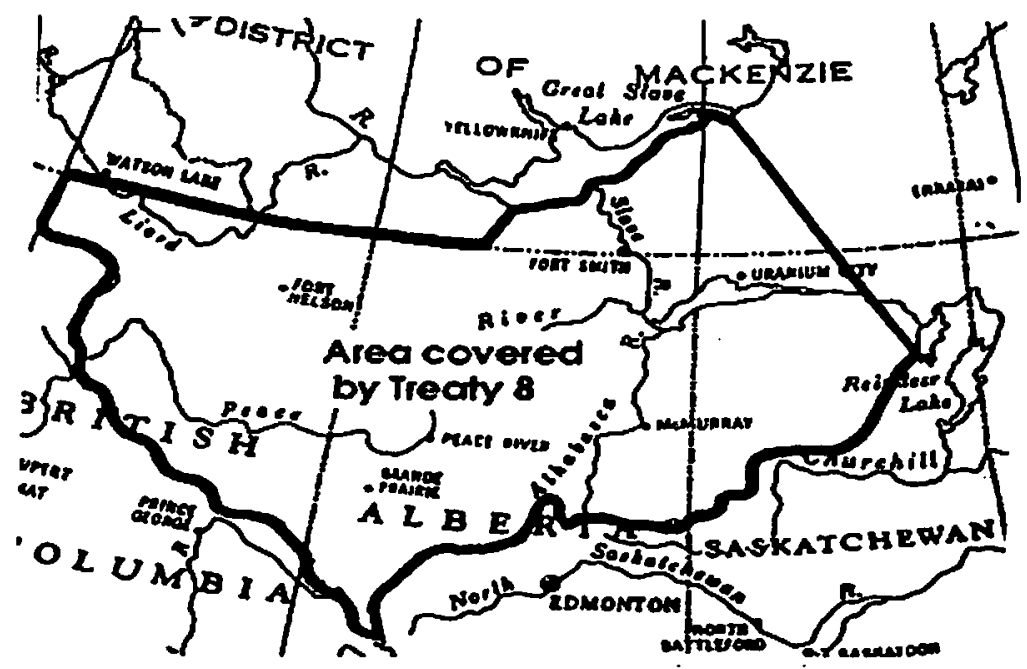

The essential elements of Treaty 8 , for the purposes of this article, may be drawn from the following passages:

AND WHereas, the said Commissioners have proceeded to negotiate a treaty with the Cree, Beaver, Chipewyan and other Indians, inhabiting the district hereinafter defined and described, and the same has been agreed upon and concluded by the respective bands at the dates mentioned hereunder, the said Indians Do Hereby Cede. Release, SURRender anU Yiet.o Up to the Govemment of the Dominion of Canada, for Her Majesty the Queen and Her successors for ever, all their rights, titles and privileges whatsocver, to the lands included within the following limits, that is to say ... [ [here follows a description of the lands of Treaty 8]

19 Reproduced from Heritage Community Foundation, online: Alberta Source <www.albertasource. ca/treaty8/eng/default.htm>. 
AND ALSO the said Indian rights, titles and privileges whatsoever to all other lands wherever siluated in the Northwest Territories, British Columbia, or in any other portion of the Dominion of Canada.

To Have And to Hol.D the same to Her Majesty the Queen and Her successors for ever.

AND Her Majesty the Queen IIEREBY AGREES with the said Indians that they shall have right to pursue their usual vocations of hunting, trapping and fishing throughout the tract surrendered as heretofore described, subject to such regulations as may from time to time be made by the Government of the country, acting under the authority of Her Majesty. and siving and excepting such tracts as may be required or taken up from time to time for settlement, mining. lumbering, trading or other purposes. ${ }^{20}$

The historical context of Treaty 8 has been the subject of extensive review elsewhere, and will not be discussed in detail here. ${ }^{21}$ Extrinsic evidence has been used to provide the context within which to interpret Treaty 8 . The purpose of Treaty 8 , from the perspective of the Canadian government, was described by Wilson J. as follows:

In one of the most detailed studies of the history of the negotiations leading up to Treaty No. 8, As Long as this Lome Shall Last: A I/istory of Treaty 8 and Treaty 1/, 1870-1939(1973), R. Fumoleau explains why the Canadian govemment sought an agreement with the Treaty 8 Indians. The Klondyke gold rush gave rise to serious problems throughout 1897 to 1898, with miners travelling through territory occupied by the Indians and paying little respect to their traditional way of life. Inevitably conflict broke out as the Indians retaliated. The govermment of Canada quickly realized that it was necessary to reach an understanding with the Indians about future relations. Commissioners Laird, Ross and McKenna were therefore sent out to negotiatc a treaty with the Indians. 22

The protection of hunting and fishing rights was critical to the Government's success in obtaining a treaty. The "Report of Commissioners for Treaty No. 8" made this point abundantly clear:

Our chier difficulty was the apprehension that the hunting and fishing privileges were to be curtailed. The provision of the treaty under which ammunition and twine is to be furnished went far in the direction of quicting the fears of the Indians, for they admitted it would be unreasonable to fumish the means of hunting and fishing if laws were to be enacted which would make hunting and fishing so restricted as to render it impossible to make a livelihood by such pursuits. But over and above the provision, we had to solemnly assure them that only such laws as to hunting and fishing as were in the interest of the Indians and were found necessary in order to protect the fish and fur-bearing animals would be made, and that they would be as free to hunt and fish after the treaty as they would be if they never entered into it. ${ }^{23}$

: Sec e.g., Rene Fumoleau. As Long as this Lamd Shall Last: A IIisfory of Treaty 8 and Treany 11. 1870. 1939 (Calgary: University of Calgary Press. 2004).

$\because \quad$ R. v. Horseman, [1990] I S.C.R. 901 at 909 [Horseman]. While Wilson J. was writing in dissent, her description of Treaty' \&'s purpose does not appear to be controversial.

2) David Laird, J.H. Ross \& J.A.J. McKenna. "Report of Commissioners for Treaty No. 8" in Treaty 8 , supra note 7, 5 at 6 [Commissioners' Report]. This passage was quoted in both the majority and dissenting judgments in Horseman, ibid. at 910 per Wilson J. and at 929 per Cory J. 
The Commissioners' Report, however, is not the last word regarding the nature of hunting, fishing, and trapping rights in Treaty 8. Despite the observation that "it would be unreasonable to furnish the means of hunting and fishing if laws were to be enacted which would make hunting and fishing so restrictive as to render it impossible to make a livelihood," and despite the solemn assurance that "they would be as free to hunt and fish after the treaty as they would be if they never entered into it," hunting, fishing, and trapping rights in both Alberta and Saskatchewan were modified by para. 12 of the Natural Resources Transfer Agreement (NRTA). ${ }^{24}$ Paragraph 12 of the NRTA modified the Treaty $\&$ rights to hunt, fish, and trap throughout "the tract surrendered" by limiting the protection of those rights by Treaty 8 to hunting, fishing, and trapping "for food," and by expanding the geographic scope over which those rights may be exercised to all unoccupied Crown lands in the province: that is, land that is put to no "visible, incompatible land use," and lands that the Indians have a right of access. ${ }^{26}$

On the face of the Treaty and the $N R T A$, the treaty rights to hunt, fish, and trap do not appear to be site-specific or to recognize the unique traditions or culture of each of the First Nations that are signatories to the Treaty. The language describing those rights and their limitations, both in the Treany and in the NRTA, makes no reference to the traditional range of each First Nation, or to any other site-specific formulation of those rights.

However, Treaty 8 was clearly made in the context of particular Aboriginal groups and their pre-existing ways of life, and recognizes at least some unique characteristics of their differing ways of life in its terms. For example, the means of assistance provided to First Nations in Treaty 8 were made flexible to recognize the different opportunities available to, and the varying interests of, each group within the territory. Assistance in the form of seed, implements, and cattle was made available to those that wished to take up farming. Cattle and mowers were available to those who wanted to take up cattle raising. Ammunition and twine were given to those who continued to fish and hunt. ${ }^{27}$ The Commissioners also noted other differences between the Indians that took treaty under Treaty 8 and the "Indians of the organized territories," including differences in dress, form of shelter, language, and religion. They noted that the tribes did not appear to have any definite organization and that hunting in the North differed from hunting on the plains in that the Indians hunt in a wooded country and, instead of moving in bands, go individually or in family groups. ${ }^{28}$

Despite the common language used to describe the hunting, fishing, and trapping rights of the First Nations that are signatories to Treaty 8 (and indeed, in the other numbered

24 Natural Resources Transfer Agreemem, confirmed by the Constiumion Act, 1930, 20 \& 21. Geo. 5, c. 26 (U.K.) [ruprinted in R.S.C. 1985, App. II, No. 26], s. I.

$\because \quad$ In contrast lo commercial purposes, which the original Treaty rights elearly included ( $/$ /orseman. supra nole 22 at 930 ).

: Horsemen, ibid. and R. 1. Busdger. [1996] I S.C.R. 771. See also Mikisew (C.A.). supra note 1. which clarifies that para. 12 of the NRTA does not apply within Wood Buffalo National Park.

" Commissioners' Report, supra note 23 at 7. The Commissioners noted that farming and ranching were likely to be lairly limited and that it could be expected that the great majority would continue to hunt and fish for a livelihood. 
treaties), it appears to be clear from the case law that the specific rights that are protected by the Treaty will differ from group to group. In $R v$. Sundown, Cory J. stated as follows:

Trealy rights, like aboriginal rights, are specific and may be exercised exclusively by the First Nation that signed the treaty. The interpretation of each treaty must take into accormt the First Nation signatory and the circumstances that surrounded the signing of the treaty. Lamer C.J. was careful to stress the specific nature of aboriginal rights in R. v. Van der Peet, [1996] 2 S.C.R. 507. At para. 69 he wrote:

The fact that one group of aboriginal people has an aboriginal right to do a particular thing will not be. without something more, sufficient to demonstrate that another alboriginal community has the same aboriginal right. The existence of the right will be specific to each aboriginal community. [Emphasis added.]

This principle is equally applicable to treaty rights. Dickson C.J. and LaForest J. also emphasized the specific nalure of aboriginal and treaty rights in $R$. 1 . Sparrow, [1990] I S.C.R. 1075, when they discussed the correct test to apply under s. 35(1) of the Constitution ACt. 1982. At page 1111 this appears:

We wish to emphasize the importance of context and a case-by-case approach to s. 35(1). Given the generality of the text of the constitutional provision, and especially in light of the complexities of aboriginal history, society and rights, the contours of a justificatory standard must be defined in the specific factual context of each casc. [Limphasis added.]

Thus, in addition to applying the guiding principles of treaty interpretation, it is necessary to take into account the circumstances surmunding the signing of the treaty and the First Nations who later adhered to it. For example. consideration. should be given to the evidence as to where the huming and fishing were done and how the members of the First Nation carried out these activities. ${ }^{29}$

Accordingly, notwithstanding the apparent simplicity of the operative words of Treaty 8 , the actual treaty rights in issue in any particular case will likely have some site-specific character.

It is also necessary, as alluded to by Cory J., to apply the "guiding principles of treaty interpretation" in determining the specific rights in issuc. ${ }^{30}$ These principles include the principle that a treaty is to be liberally construed. ${ }^{31}$ This means that treaties must be interpreted not in their technical or legal sense, but in the sense that they would have been understood by the Aboriginal group in question at the time of signing.

Given the emphasis on the historical context referred to in the passage from Sundown above, and on the principle of liberal construction, extrinsic evidence regarding the circumstances within which a First Nation signed the treaty may play a role in determining the nature of the treaty rights in a given area, and the subsequent application of the Sparrow

Nowegijick v. R., [1983] I S.C.R. 29. A full discussion of the principles of interpretation of treatics is beyond the scope of this article. For a general discussion of this issue see Jack Woodward, Native Law' (Toronto: Carswell, 1990) at 404.406. 
and, perhaps, Ilaida analyses to these rights. ${ }^{32}$ In $R$. v. Marshall, the Supreme Court of Canada expressed the following rules regarding the use of extrinsic evidence in the interpretation of treaties:

1. Extrinsic evidence can be used to "show that a written document does not include all of the terms of an agreement" and it can also be used to then supply missing terms;

2. Historical and cultural context can be used as interpretive aids even if the treaty document purports to contain all of the terms and even absent any ambiguity on its face;

3. An overly deferential attitude to the written document is inconsistent with a proper recognition of the difficulties of proof facing aboriginal people. ${ }^{33}$

Sources of extrinsic evidence, beyond the Commissioners' Report, have been advanced from time to time to aid in the interpretation of the rights granted to First Nations under Treaty 8. For example, in Dene Tha' First Nation v. Alberta (Energy and Uitities Board), the Dene Tha' sought to rely on the affidavits of James Kennedy Cornwall, sworn 1 November 1937, and Gabriel Breynat, sworn 26 November $1937 .{ }^{34}$ Both of these affidavits contain references to oral promises made by the Commissioners.

Mr. Cornwall deposes that he was present when Treaty 8 was made at Lesser Slave Lake and Peace River Crossing. ${ }^{35} \mathrm{Mr}$. Cornwall's affidavit goes on to read:

2. The Treaty presented by the Commissioners to the Indians for their approval and signatures was apparently prepared elsewhere, as it did not contain many things that they held to be of vital importance to their future existence as hunters and trappers and fishermen, free from the competition of white men. They refused to sign the Treaty as read to them by the Chicl Commissioner.

3. Long discussions took place between the Commissioners and the Indian Chiefs and Headman, with many prominent men of the various bands taking place. The discussion went on for days, the Commissioner had unfavourably impressed the Indians, by quoting Indian conditions on the Prairie. Chief Mostoos (the Buffalo) disposed of the argument by telling the Chief Commissioner "that a Plains Indian turned loose in the hush would get lost and starve to death."

Supra note 1. The application of the Haida principles to treaty rights has not been determined. In the context of this discussion, where treaty "rights" may be asserted that are not apparent on the express words of Treary 8 itself, it can be argued that /faida should apply. As indicated, there may be some resolution of this issue in the Supreme Court of Canada's decision in Mikise'w, stupra note 1. [1999] 3 S.C.R. 456 at paras. 10-12. However, there "is a boundary that must not be crossed between a sensitive application and a complete abandonment of the rules of evidence": Mirchell $\mathrm{v}$. Minisfer of National Revenut. [2001] I S.C.R. 911,2001 SCC 33 at para. 39. 2005 ABCA 68, leave to appeal to the S.C.C. refused, [2005] S.C.C.A. No. 176, Vol. I, at 22 and 25. respectively [Dene Tha' Leave Materials]. 
5. The Commissioners finally decided, after going into the whole situation, that what the Indians suggested was only fair and right but that they had no authority to write it into the Treaty, but felt sure the Govemment on behalf of the Crown and the Great White Mother would include their request and they made the following promises to the Indians: -

(a)

The old and destitute would always be taken care of, their future existence would be carefully studied and provided for and every effort would be made to improve their living conditions.

(c)

\begin{abstract}
They were guarantecd that they would be protected in their way of living as hunters and trappers from white competition, they would not be prevented from hunting and fishing as they had always done, so as to enable them to earn their own living and maintuin their existence.
\end{abstract}

6. Much stress was laid on one point by the Indians, as follows: They would not sign under any circumstances, unless their right to hunt, trap and fish was guaranteed and it must be understood that these rights they would never surrender.

7. It was only anter the Royal Commission had recognized that the demands of the Indians were legitimate, and had solemnly promised that such demands would be granted by the Crown, and, also after the Hudson's Bay Company Officials and Free Traders and the Missionaries, with their Bishops, who had the full confidenee of the Indians, and had given their word that they could fully rely on the promises made in the name of QUEEN VICTORIA, that the Indians accepted and signed the Treaty, which was to last as long as the grass grew, the river ran and the sun shone - to an Indian this means FOREVER. ${ }^{36}$

Vicar Apostolic Breynat deposes that he was present when Treaty 8 was signed at both Fort Chipewyan and Fond du Lac. Vicar Breynat's affidavit is to similar effect as Mr. Cornwall's. $^{37}$

Based on these materials and their oral histories, the Dene Tha' take the position that, under Treaty 8, they have various rights and entitlements owed to them by the Crown in Right of Canada and the Province of Alberta. These include:

(i) the establishment of peaceful relations between the Dene Tha' and the Crown;

(ii) economic assistance;

(iii) the guarantee of "askiwipimachihowascikewina," their way of living on the land and, in particular, the right to hunt, fish, and trap without interference; 
(iv) education;

(v) health care;

(vi) self-government; and

(vii) entitlement to natural resources. ${ }^{3 *}$

In the Dene Tha' appeal, the Court refused to consider the Cornwall and Breynat materials, along with others, on the basis that they had not been before the Alberta Energy and Utilities Board (AEUB). However, the court did not comment on their general admissibility. The Breynat affidavit was referred to in both Halfway River and Mikisew. ${ }^{34}$

\section{TREATY 8 FIRST NATIONS}

As indicated above, the actual treaty rights at issue in any particular case may have a sitespecific character and be influenced by evidence concerning individual First Nations' circumstances and understandings. Beyond this fact, publicly available information can identify areas of particular concern, means of carrying out traditional activities, site-specific information, and other information that can be useful in both conducting an initial risk assessment and, potentially, in undertaking consultation with a First Nation.

The following discussion illustrates some of the information that is available with respect to certain First Nations in the Treaty 8 area and the sources of this information. The First Nations have been selected to provide some variety in geographical location, language, and history. It is intended to be expositive rather than exhaustive and, where it refers to evidence filed, makes no assessment of the veracity or credibility of that evidence.

\section{A. Saulteau First Nation}

The Saulteau First Nation (the SFN) is a band, within the meaning of the Indian Act, ${ }^{40}$ located at the east end of Moberly Lake, approximately $150 \mathrm{~km}$ from Fort St. John in northeast British Columbia. The SFN consists of persons of Cree, Beaver, and Dene descent. and its members are recognized as being beneficiaries of Treaty $8 .{ }^{41}$ The band is made up of five "clans": Courtoreille, Davis, Desjarlais, Gauthier, and Napoleon."

Dene Tha' Leave Materials, ibid. (Evidence. affidavit of Ken Rich, swom 6 April 2005 at para. 7) [Rich Affidavit].

39 In Halfugy River (C.A.), supra note 3, the Breynat affidavit was found to be inadmissible because it was not properly proven (at para. 120). In Mikisew (C.A.), supra note I. Ilansen J. accepted the affidavit, but concluded (at para. 48) that the oral promises spoken to in the allidavit simply corroboraled other evidence, such as the Commissiontrs' Report. 2004 BCSC 92 at para. 9, aff (2004), 201 B.C.A.C. 78.2004 BCCA 286, leave to appeal to S.C.C. refused, [2004] S.C.C.A. No. 34 ! [Apsassin].

4: Saulteau Indian Band v. Totusek, 2002 FCT 132 at para. 4 [Totusck] and Napoleon v. Garbitr. [1997] B.C.J. No. 1250 (QL) at para. 3 [Napoleon]. 
The SFN have been involved in a number of court proceedings including: a challenge to Amoco's proposed Mt. Monteith well; ${ }^{43}$ the more recent proceedings whereby the SFN sought an order, inter alia, setting aside a well authorization granted by the British Columbia Oil and Gas Commission to Vintage Petroleum; ${ }^{44}$ and at least two court actions involving internal governance matters. ${ }^{45}$ Other publicly available material on the SFN include materials filed by the Treaty 8 Tribal Association in the British Columbia Utilities Commission (BCUC) hearings on BC Hydro's Site $\mathrm{C}$ application, ${ }^{46}$ and various testimony during these proceedings. $^{47}$

\section{Early Occupation and the Origins of the Saulteau First Nation}

According to The Two Mountains that Sit Together: An Ethno-Historical Overview, filed in the Amoco proceedings, the archaeological record indicates that human occupation of the Peace River region dates back some 10,500 years. ${ }^{d 9}$ While the artifact count and visibility of archaeological material in the region is low, the materials indicate that low artifact counts cannot be taken as indicative of low use. There are a number of problems regarding the archaeological visibility of boreal forest societies and economic activities. These include poor preservation of materials, disruptions of material, the locations of artifacts in areas without deposition and without apparent connections to resource-use or settlement patterns, and socioeconomic strategies and cultural precepts that influenced the diversity of remains reaching the archaeological record in the first place (that is, Northern Athapaskans valued simple ways of accomplishing things). ${ }^{\mathbf{S 0}}$

According to Weinstein, the origins of the SFN are "enshrouded in the mists of history." $\$ 1$ The Two Moumtains Study indicates that Alexander MacKenzie reported making contact with the Cree and Saulteau people near present-day Hudson's Hope when he passed through the area in 1793, but there is no documentary evidence that links these people with the present day SFN. ${ }^{52}$

Kelly Lake Cree Nation v: Canada (Minister of Energy and Mfines), [1998] B.C.J. No. 247 ( (S.C.) (QL) [Calliou].

4. Apsassin, supres nolc 41.

4) Tolusek, supra note $\mathbf{4 2}$ and Napoleon, supro note 42.

4s British Columbia Utilities Commission, BC Hydro Application for an Energy Project Certilicate for the Peace Site C Generation-Transmission Project [BCUC Site C Proceedings]; Exhibit 373, H. Brody, Maps and Dreams - Indians and the British Columbia Frontier (Vancouver: Douglas \& Melntyre, 1981) [Maps and Dreams]; and Exhibit 374, Union of B.C. Indian Chiefs, "Final Submission on the Northeast B.C. Land Use and Occupancy Study" February 1980, for the Department of Indian Affairs [B.C. Indian Chiefs]. The latter exhibit includes, as Appendix I, a 1979 study by Martin Weinstein entitled, Indian Land Use and Occupancy in the Peace River Country of Northeastern British Columbia [Weinstein]. See e.g., BCUC Cite C Proceedings, ibid., Proceedings at Hearing, Vol. 92, at 15085-87, Mr. S. Napoleon.

Treaty \& Tribal Association. The Two Mountains that Sis Together: An Ethro-Historical Oterview (December 1992), In fulfilment of B.C. Energy Mines \& Petroleum Research Contract H93-376 [Two Mountains Study].

Ibid. at 24.

Weinstein, supra note 46 at 140.

lbid. at 93. 
It appears generally accepted that a number of Saulteau families came into the Moberly Lake area around the turn of the last century. ${ }^{53}$ Madeline Davis is a direct descendent of the Saulteau prophet, Kakagooganis, the spiritual leader of the Saulteau. Ms. Davis deposed in the Amoco proceedings:

3. The Saulteau people originally came to this place from Manitoba at a time when Kakagooganis was their leader. As a result of his vision of the Two Mountains That Sit Together, he lead our people on a 10 or 12 year joumey across the prairies until we arrived where we live now. This was late in the last century. The following is the story of his prophecy:

The Saulteau people were in the midst of hard times in Manitoba. The Creator had pity of Kakagooganis, and gave him a vision for him to follow with his women and children. The Creator told him that there is land over there, at the Two Mountains That Sit Together that will provide good health for the people. Kakagooganis must have been a very gifted person to have been shown that vision. He must have been very knowledgeable in spiritual matters to have seen the Two Mountains That Sil Together from Manitoba. This is not to be taken lightly.

The vision come to him like this. He died for ten days, and only his heart moved. While he was in this state, he talked to the Creator, who gave him the vision of the Two Mountains That Sit Together, with a bottomless lake below them. He was told this would be sanctuary for his people in times of flood and heat, a time when the world ends.

After the ten days, he came alive and told his people of his vision. They then travelled slowly westward until they came to the Two Mountains That Sit Together and Moberly Lake, where we are now. The prophecy makes the land sacred to my people through its life-giving nature. It was given in us by the Creator through my grandfather. ${ }^{54}$

The Saulteau were not one of the original signatories to Treaty 8 . They adhered to Treaty 8 in $1914 .^{5 s}$

\section{AREAS OF INTEREST AND TRADITIONAL ACTIVITIES}

The documents indicate a number of areas of significant interest to the Saulteau and, in some cases, past and present activities in these areas, including certain site-specific information.

\section{a. Area of Critical Community Interest}

In Maps and Dreams, Brody indicates that seven hunters at "East Moberly Lake" drew separate maps of their land use before and since 1961. Composite maps were then prepared

\$7 Two Mountains Srudy, supra note 48 at 1.

st Calliou, supra nole 43 (Evidence, aflidavil of Madeline Davis, swom 3 September 1998 at paras. 1-3) [Davis Aflidavit].

3s Apsassin, supra note 41 (Evidence, affidavit \#I of Alan Apsassin, swom 12 August 2003 at para. 3) [Apsassin Affidavit]. Exhibit " $A$ " is a copy of the first annuity payment list for Saulteau members dated 11 June 1914. 
showing these hunting areas for both time periods. ${ }^{56}$ The post-1961 map shows a concentration in the total area used, particularly from the west and the south. This was attributed to "great pressure on their land from white settlement and development." These maps were reproduced and relied on in the Final Submission on the Northeast B.C. Land Use and Occupancy Study prepared by the Union of B.C. Indian Chiefs, and filed by the Treaty 8 Tribal Association in the BCUC Site $\mathrm{C}$ proceedings. ${ }^{58}$

According to an affidavit sworn by Matthew General in the Apsassin action, while SFN members are entitled to, and do, exercise their treaty rights throughout the Treaty 8 territory, SFN members intensively exercise, and have exercised, their rights in a smaller part of this territory situated around and in the vicinity of their reserve on Moberly Lake. ${ }^{59}$ This area has been referred to as the Area of Critical Community Interest (ACCl), or the Area of Critical Community Use. The ACCI corresponds with the northern portion of Brody's post-1961 map, but does not contain any of the previously marked areas south of the Pine River. ${ }^{60}$ The $\mathrm{ACCl}$ also roughly corresponds with the location of Saulteau traplines, again with the exception of certain traplines to the south. ${ }^{61}$

In many cases, Aboriginal hunting and trapping activities took place in the same general area. Accordingly, there may be an inclination to attempt to equate traditional use areas with areas occupied by Aboriginal traplines. While there are some parts of the ACCI that do not contain Saulteau traplines, materials in the Two Mountains Study caution against placing too much reliance on the location of Aboriginal traplines to indicate areas of historic use. In many cases, tracts of "Indian land" were "taken away through a trapline registration system introduced in the 1920s, which resulted in the registration of Indian hunting and trapping lands by non-Indian trappers." ${ }^{21}$ As the Two Mounsains Study indicates:

In an article titled "Peace River Trap Lines", Slaff Sergeant G.J. Duncan wrote about his experiences in the

Peace River in 1914:

I soon found out that there was hardly a family [of settlers] which did not have some member engaged in trapping as a sidelinc, and in many cases trapping was the sole source of income.

[Sergeant Duncan] issued 48 [trapping] licences in the fall of 1915, and recorded lines of four Indian trappers, who were allowed to trap without licences. He made the trappers mark their lines on a map, then gave a licence, and argued that:

"9. Apsassin. supra note 4l (Evidence, atlidavil $\# 1$ of Matthew General. swom 30 July 2003 at para. 9) [General Affidavit].

Maps and Dreams, supra note 46 at 164.

lbid. Ibid., Exhibit "A."

Apsassin, supra nolc 41 (Evidence, affidavil \#1 of Karl Kliparchuk, swom 3 September 2003, Exhibit "G").

Two Moumtains Sudu, stpra note 48 at 51 . 
By adopting this method there were very lew disputes to settle, as the only ones that arose were when Indians returned to lines that they had run some years previously and found they had been taken up by white trappers. ${ }^{63}$

To restore Indian hunting and trapping territories in the 1930s and 1940s, the Department of Indian Affairs began buying back traplines to return to Indian trappers and hunters, but apparently no more funds were allocated for this purpose. ${ }^{6.4}$

Substantial parts of the $\mathrm{ACCl}$ have been developed for a wide variety of commercial and public purposes in recent years. These include oil and gas development, forestry, mining. hydro-electric power, road building and maintenance, agricultural operations, and general settlement. The SFN indicate that the cumulative effect of all of these developments has been to significantly limit, restrict, or curtail the ability of SFN members to exercise their treaty rights in the $\mathrm{ACCl} .{ }^{65}$

According to the SFN, the British Columbia Ministry of Energy and Mines (MEM) and the British Columbia Oil and Gas Commission (OGC) are aware of both the significance and special nature of the ACCI to the SFN, and the negative effects of oil and gas activity on their ability to exercise their treaty rights. ${ }^{\text {bf }}$ The MEM is responsible for granting drilling licences in British Columbia. ${ }^{67}$ The OGC is responsible for authorizing oil and gas activities. ${ }^{68}$ The Province of British Columbia has previously conceded that, given the SFN's treaty rights, it has a duty to consult with the SFN where the SFN may be affected by industrial activities. ${ }^{69}$

\section{b. The Peace-Moberly Tract}

Within the ACCl is a tract of land between Moberly Lake and the Peace River (the PeaceMoberly Tract) that has not been subject to significant oil and gas exploration or development, and has not been subject to any significant amount of other development. ${ }^{70}$ According to materials in the Apsassin action, the Peace-Moberly Tract is the last significant area of land that is available in the ACCI for the reasonable exercise of the Saulteau's treaty rights and that, given the close proximity of this area to the SFN, the area is of special significance and is heavily relied on by community members for sustenance, cultural, commercial, and socio-economic purposes. These activities include, inter alia: hunting for large and small game, including moose; trapping for fur-bearing animals, including marten, squirrel, rabbit, coyote, and weasel; fishing; and carrying out activities that are incidental to the rights set out in Treaty 8 , including the building and maintaining of cabins, camping on

Ibid. at 53.

Ibid. at 57.59 .

Generul Alfidavit, supros note 59 at para. 11.

Ibid. al paras. 9.10.

Petroleum and Natural Gas Act. R.S.B.C. 1996, c. 361: Petroleum and Natural Gas Drilling Licence

Regulation, B.C. Reg. 10/82.

Oil and Gas Commission Act, S.B.C. 1998, c. 39, s. 17.

Calliou, supra note 43 at para. 29.

Gencral Affidavit, supra note 59 at para. 12. 
the land, the building of trails and other infrastructure associated with hunting, fishing, and trapping, and gathering berries, medicinal plants, and other food sources on the land. ${ }^{71}$

The Peace-Moberly Tract has been referred to as the community's "grocery store." There are areas in the Peace-Moberly Tract that are known as "White Mud," or white mud areas. Moose frequent these areas and extensively use the trails that connect the areas. ${ }^{22}$ Some "trails and licks" have tracks as deep as 18 inches, which means that a large number of animals depend on these important trail-lick systems. There are some licks where a hunter only has to wait "minutes" for a moose to show up. ${ }^{3}$ The SFN also indicate that there are known gravesites, spiritual sites, and traditional place names in the area. ${ }^{74}$

According to the Apsassin materials, in recent years the Peace-Moberly Tract has been subject to increased pressures that threaten the ability of the SFN to exercise their treaty rights on account of development elsewhere in the ACCI, and in nearby areas of Treaty 8 . These pressures include:

(i) SFN members who hunted, lished, and trapped elsewhere in the $\mathrm{ACCl}$ carrying out these activities in the Peace-Moberly Tract;

(ii) similarly, other Treaty 8 First Nations coming to the Peace-Moberly Tract to exercise their rights;

(iii) increased draws on local resources as a result of displaced animal populations moving into the Peace-Moberly Tract; and

(iv) increased hunting pressure from non-Aboriginal hunters. ${ }^{75}$

The SFN indicate that these concerns have also been made known to both the MEM and the OGC. ${ }^{76}$

c. The Two Mountains that Sit Together

To the west and south of the Peace-Moberly Tract are the Two Mountains that Sit Together, also known as the Twin Sisters/Beattie Peaks. The Twin Sisters are a sacred area

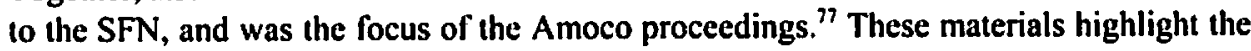
significance of this area to the SFN and the extent of the area.

Jbid. al para. 13.

Apsassin Aflidavit, supra note 55 at para. 6.

Apsassin, supra note 41 (Evidence, altidavit \#1 of Bev Rohel, sworn 12 August 2003 at para. 10).

Ibid. at paras, 14, 52.

General Affidavit, supra note 59 at paras. 16-17.

Ibid. at para. 18.

Calliou, supra note 43 (Evidence, affidavit of Marvin Desjarlais, swom 4 September 1998) [Desjarlais Affidavit]. 
In 1987. Dome Petroleum and another oil company were granted a drilling licence in the general area that the Twin Sisters are located. Amoco acquired Dome in 1988, ${ }^{78}$ and by 1991 , believed that it had identified certain anomalies indicative of the existence of a substantial deposit of gas. As a result, it applied for permission to drill an exploratory well on the slopes of the Twin Sisters. ${ }^{79}$ Given the nature of the area and initial expressions of concern by various First Nations in the area, the Two Mountains Study was undertaken in $1992 .{ }^{80}$ The Two Mounfains Study outlines the history, use, and importance of the Twin Sisters area to First Nations in the area, including the SFN. ${ }^{81}$

The immediate result of the Two Mountains Study was that Amoco would not be permitted to drill in the slopes of the Twin Sisters. ${ }^{82}$ Further discussions, studies, and processes took place. Finally, in June of 1997, Amoco filed an application for approval to drill an exploratory well below Mt. Monteith. ${ }^{83}$ The proposed wellsite was on a flattened area between the two mountains, approximately $3.8 \mathrm{~km}$ from the closest of the two peaks. ${ }^{84}$

Following further meetings and consultations, on 23 July 1998, the MEM approved Amoco's application. ${ }^{85}$ The SFN and the Kelly Lake Cree Nation opposed this decision and an ancillary decision by the Ministry of Forests. The SFN's opposition was based in part on an argument that the MEM had erred in its determination of the extent of the sacred area in the Twin Sisters area. ${ }^{86}$ The SFN took the position that this area was much broader than concluded by the decision maker, included the area of the proposed wellsite, and filed affidavit material in support of this position. As indicated by Madeline Davis:

4. The area between the Twin Sisters and Mount Monteith is all part of the sacred area that the prophecy talks about. The prophecy says that our people must keep the whole Twin Sisters area elean so it can be used by our people as a reluge.

7. The idea that the sacred area is just the two mountains alone is ridiculous. What use would the mountains be to us without the valley and surrounding arcas? How would this be a refuge as the prophecy says? How ane our people going to survive if they cannot hunt and sustain themselves in the whole area? How can the moose, rabbits and even fish survive without the whole area? The sacredness of the Two Mounlains That Sit Together to the Saulteau people comes from the tife-giving nalure of the whole area.

lbid.

lbid. at para. 46.

Ibid. at para. 80.

lbid. at para. 13.

Ibid. at paras. $81-118$.

Ibid. at paras. 226-29.

Davis Affidavil, stupra note 54. See also, inter alia, Desjarlais Aflidavit, supra note 77; Calliou, ibid. (Evidence, affidavit of Suzette Napoleon, stwom 3 September 1998); and Callion, ibid. (Evidence, affidavit of Raymond Napoleon, sworn 3 September 1998). 
Justice Taylor found that the MEM had considered this issue and clearly understood the significance of the area in question. ${ }^{\mathrm{kB}} \mathrm{He}$ also dismissed the other arguments of the SFN and Kelly Lake First Nation. Ultimately, Amoco's well was unsuccessful.

\section{B. The DENE Tha' First Nation}

\section{INTRODUCTION}

The Dene Tha' are Athapaskan speaking people, whose traditional territory extends from northwest Alberta into northeast British Columbia, and the southern Northwest Territories. Until quite recently, the Dene Tha' lived a nomadic and subsistence-based lifestyle. ${ }^{89}$

Starting in the early 1900 s, semi-permanent settlements based on family groups or "clans," were established around major waterways within the traditional territory, providing a home base for year-round activities. It was at this time that trading posts were established throughout the area by the Hudson's Bay Company. However, unlike many of their Aboriginal counterparts to the south, large scale contact with missionaries, traders, and government authorities did not occur until well into the 20 th century. Throughout the early 1950s, most people moved to Habay and Meander River from the outlying smaller settlements. Then, in 1962, most Dene Tha' abandoned Habay to permanently settle in Chateh following a major flood. ${ }^{90}$ The Dene Tha' are now primarily divided into three communities: Bushe River, Meander River, and Chateh, and have seven reserves totalling approximately 30,038 hectares. ${ }^{91}$ The Dene Tha' are descendants of signatories to Treaty $8 .{ }^{92}$

\section{MATERIALS}

The Dene Tha' have a website at www.denetha.ca. They have been involved in a number of court proceedings. In December 2002, the Dene Tha' filed an objection with the AEUB to a number of applications by Penn West Petroleum Limited. When this application and a subsequent review and variance application were dismissed by the AEUB, the Dene Tha' sought and obtained leave to appeal this decision to the Alberta Court of Appeal. This appeal was dismissed. The Dene Tha' then sought leave to appeal at the Supreme Court of Canada and were subsequently denied in $2005 . .^{93}$

On I February 2005, the Dene Tha' filed an Originating Motion in the Alberta Court of Queen's Bench, seeking an injunction against Alberta Sustainable Resource Development

Calliou. ibid. at para. 229.

Dene Tha' Leave Materials, supro note 34, (Evidenee, Dene Tha' Traditional Land-Use and Occupancy Siudy at 18 [Dene Tha' TLUOS]).

Dene Tha' TLUOS, ibid. at 18-19, 26.

Amber River No. 211 , Bistcho Lake No. 213, Bushe River No. 207, Hay Lake No. 209, Jackfish Point No. 214, Upper Hay Reserve No. 212, and Zarna Lake No. 210.

Rich Aflidavil, supra note 38 at para. 3.

Supra note 34. 
and Apache Canada Ltd. ${ }^{94}$ The Dene Tha' filed a number of affidavits in support of this application. ${ }^{95}$

On 17 May 2005, the Dene Tha' filed an application in Federal Court against numerous parties connected with the Mackenzie Gas Project. ${ }^{\% 6}$ The Dene Tha' have also filed evidence in the Mackenzie Gas Project proceedings before the National Energy Board. ${ }^{97}$

Similar to the SFN, there are various references throughout these materials to areas of interest, traditional activities, the importance of these activities to the Dene Tha', and various site-specific information. For example, the seasonal migration routes of the originally nomadic Dene Tha' are described by the Elders as "traveling in a 'circular motion', from Tu Lonh (End of the Water), to Long Lake (Rainbow Lake), to Tamarack Hill, to Tsa Zaghe (Beaver Creek tributary), and back to Tu Lonh."98 The Dene Tha' indicate that the "bush economy" of the Dene Tha' depends on the animals hunted and plants gathered for food: moose, caribou, deer, bears, rabbits, chickens, ducks, duck eggs, martens, porcupines, beavers, squirrels, crawberries, strawberries, ground cranberries, choke cherries, saskatoons, raspberries, Canadian buffalo berry, bunch berries, wild onions, and parsnips. Furs from lynx, marten, fox, beaver, and muskrat are trapped for trade and income. The numbers and location of these animals and plants are, in turn, affected by changes to the habitat.99

\section{TRADITIONAL LAND USE AND OCCUPANCY STUDY}

Of particular interest in terms of the nature and format of information available to the Dene Tha' is the Dene Tha' Traditional Land Use and Occupancy Study (the Dene Tha' TLUOS), filed in support of the Dene Tha's leave application to the Supreme Court of Canada in the Penn West proceedings. ${ }^{100}$ The Dene Tha' TLUOS provides information that would be relevant to a risk assessment and may assist with consultation efforts.

As described by the Dene Tha', the TLUOS project presented the first opportunity to accurately record their traditional and cultural presence on their land. ${ }^{101}$ Phase 1 of the project commenced in January 1996. In consultation with Chief and Council, a comprehensive list of elders, hunters, and trappers was compiled by three community researchers. ${ }^{102}$ Ultimately a total of 70 elders, hunters, and trappers from all three Dene Tha' communities participated in Phase 1 of the project. ${ }^{103}$ Fixed site information from these interviews was transferred onto

Calgary Court Registry No. Q051 01688 [unreported] [Denc Tha' Originating Motion].

95 Dene Tha' Originating Motion, ibid. (Evidence, affidavit \#1 of Harry Natannah, sworn 27 January 2005; affidavit of Ken Rich, swom 27 January 2005; affidavil \#I of Sidncy (hambaud, swom 27 January 2005: aflidavit \#1 of Cary Chokolay, swom 27 January 2005). Court File No. T-867-05.

NEB, Hearing order GH-1-2004 (Evidence, Jetter from Chief David Moses, A0Q9L8). See "History-Migration," online: Dene Tha" First Nation <www.denetha.ca/history07.html>. Dene Tha' TLUOS, supra note 89 at 50-61.

Ibid; Dene Tha' First Nation v. Alberta (Energy and Uisitities Bourd), supra note 34.

Dene Tha' TLUOS, ibid.

Ibid. at 12-13.

Ibid. at 14. 
mapsets and then collated information was transferred onto one final 1:250,000 base map for the project. ${ }^{104}$

Phase II of the project involved digitizing the hard copy mapsets onto a computer-based geographic information system (GIS). The transferred data includes both fixed point and spatial area data and, in many cases, fixed sites were "verified in the field by obtaining accurate global positioning system (GPS) data." 105 The GPS data was acquired during intensive and sometimes lengthy field visits to the sites identified in Phase I. Field visits occurred during the months of May to September. The GPS community researcher was taken into the bush by both elders and current bush users, and was shown where major sites were located in the Dene Tha' traditional territory. In addition to personal observations made by the elders, a GPS reading of the site was also recorded. Pictures of the site were also taken. ${ }^{106}$

The GPS data was then added to the previously digitized map data to form a "comprehensive database of information which, through the GIS, can be displayed in a plotled map form containing one or more thematic layers of information" (that is, grave sites, historical sites, cabins, and the like). ${ }^{107}$

The Dene Tha' indicate that, although Phase II of the project was comprehensive, it was

impossible to undertake completely a thorough field reconnaissance of all the identified fixed sites. Many of the sites are located in remote and inaccessible locations, and Phase II of the project proceeded under fairly specific budget and timeline limitations. However, as the locations of new sites become available, they can sasily be added to the Cils database. Also, as additional ethnographic information is collected, it too can be added to the database descriptions of important sites. ${ }^{108}$

Phase Ill of the project consisted of the production of the Dene Tha' TLUOS report. In the Dene Tha's words, the final TLUOS report is a direct reflection of the words and wisdom of the Dene Tha' elders. ${ }^{109}$ The TLUOS report contains an introduction to Dene Tha', including the Dene Tha's perspective on Treaty 8 and the Dene Tha' First Nation. It also contains overview descriptions of fixed sites such as: cabins, camping places, and settlement sites; spiritual and historical sites; gravesites; hunting areas, including plant and animal information; trapping; migration trails: and place names.

The Dene Tha' have prepared a report on the utility of the 'TLUOS both to the Dene Tha' First Nation, and in communication with government and third parties who were considering activities that could affect Dene Tha' First Nation land use. ${ }^{110}$ Notwithstanding the Dene Tha' TLUOS, the Dene Tha' caution that in order to determine if a proposed well or other

Ibid. at 13.

lbid. at 9.

Ibid. at 14.

thid. at 9.

thid. al 17.

lbid. al 9.15 .

S. Horvath, L. MacKinuın, M.O. Dickurson \& M.M. Ross, "The impact of the traditional land use and occupancy study on the Dene Tha' First Nation" (Edmonton: Sustainable Forest Management Network. 2001). 
project is on a grave or some other specific site, a site inspection is required and the people who know the site have to be questioned."

\section{INFRINGEMENT}

The Dene Tha' indicate that their traditional territory has already been negatively impacted by thousands of oil and gas producing wells, thousands of kilometres of seismic lines, hundreds of kilometres of pipelines, and hundreds of kilometres of associated oil and gas activities. There are also extensive timber harvesting activities undertaken by forestry companies throughout the traditional territory, including extensive road networks. According to the Dene Tha', the effects of this development have been felt particularly intensely in the areas of the traditional territories in Alberta, and in the vicinity of their reserves. This, in turn, has caused the parts of its traditional territory situated in the northwest region of Alberta and the southern Northwest Territories to become increasingly critical for the purpose of maintaining the distinct culture and way of lile of the Dene Tha'. ${ }^{\prime 2}$

In Dene Tha 'First Nation v. Alberla (Energy and Utilities Board), the Dene Tha' outlined their objections to Penn West's applications as follows:

Based on the facts stated at the outset and the considerations raised above in demonstrating Dene Tha's rights and interests at stake, Dene 'Tha' submits that it is clear to the point of being self-evident how its rights might be directly and adversely affected by the proposed Penn West application.

Penn West proposes upwards of 30 well locations and pipelines, with associated access roads and other related development. All of this would be in traditional Dene Tha' lerritury, where Dene Tha' members continue to exereise their Treaty rights to hunt, trap and lish and pursue a traditional lifestyle. It also would directly impact on numerous Dene Tha' traplines.

The nature of this impact is immediate and obvious. Development on such a large scule threatens the traditional lifestyle of Dene Tha' members, the habilat of the wildlife on which Dene Tha' members rely. and the integrity of the lands to which the Dene Tha' have been intimately connected for hundreds of years. Specifically, the Dene Tha" are gravely concerned about impacts on wildlife populations and movements, on water courses and streams, and on plants used in traditional medicine and spiritual practices (to cite but three examples). Penn West itself has acknowledged that numerous traplines belonging to Dene Tha' members will be affected.

As noted, the impact of Penn West applications will not be confined to the lands on which the actual facilities are to be located, but will extend to adjacent and surrounding lands. Dene Tha's rights and interests attach to this entire area. When, for example, heavy equipment and aceess roads intrude into wildlife habitat. the impact on the ability of the Dene Tha" members to hunt and trap is direct. It must not be forgotten that many Dene Tha' members eam their living by hunting and trapping. and that development that inhibits such pursuits has an immediate impact on individual and community standards of living. This is to say nothing of related impacts on Dene Tha' culture, traditions and quality of litie.

11' Ibid. at para. 11.

11: Dene Tha' First Vation v. Alberfa (Energv and Utilitics Board). stupra note 34 (Notice of Application, paras. 36- 39). 
The adverse impact of the Penn West applications must also be considered in light of pre-existing oil and gas development in the area. The true effects can only be determined on a cumulative basis, having regard to the destruction of habitat and traditional lifestyle that development has already wrought. In this regard. Dene Tha' have already suffered, duc to the impact of ongoing oil and gas activity, an enormous depletion of the wildlife and supporting habital on which they depend in the exercise of their Treaty rights. Dene Tha' hunters are forced to travel ever-further a field to find meat to feed their families. Trappers have seen their catch diminish precipitously as more and more species disappear in the face of relentlessly encroaching development. The Penn West applications are a significant addition to this phenomenon that will only exacerbate an already-desperate situation. ${ }^{113}$

The AEUB found these assertions were not specific enough to establish that the Dene Tha' would be "potentially negatively or adversely affected" by Penn West's applications. ${ }^{114}$ The Court of Appeal found this was a factual finding. and that they had no jurisdiction to question it."1' While not necessary to their decision, the Court of Appeal went on to indicate as follows:

However, in case it be thought that the Board had missed some issue, or erted in something procedural, we should say one thing. Despite many opportunities, the First Nation gave the Board very little factual detail or precise information. On appeal it now asserts that the key question was adverse effect on traplines; but that is only one matter of a number vaguely assented in the letters. The letters came from the solicitors for the appellant First Nation.

The First Nation argument suggested to us that it lacked information to be mone specific. As that is said to tie into the question of consultation, we will say a little about it in deference to council. even though it is a purely factual question.

There had been discussions and provision of exact wellsite lecations long before the submissions to the Board. There never has been any suggestion that anyone lived oulside the reserve, or that any wells or roads were to be within the reserve. The First Nation must know, or be able casily to learn, where its members hunt and trap. None of that hard information was provided to the Board. Instead the solicitors gave vague and adroitly-worded asserions or rights, some of which encompassed all land in Alberta, or in any event, all Crown land in Alberia.

The First Nation also contended before us it had no duty to lell the Board specifics, and that the Board should have frozen all development while deciding the question. We cannot agree, and have seen no authority. constitutional or otherwise, requiring such a logical impasse."

\section{Mikisew Cree First Nations and Athabasca Chipeivyan First Nations}

The members of the Mikisew Cree First Nations (MCFN) and the Athabasca Chipewyan First Nations (ACFN) are descendants of the Cree and Chipewyan Indians who signed Treaty

Denc Tha' Leave Materials, stypra note 34 at 523-24.

Bbid. at 325.

Dene Tha' First Nation 1: Alberta (Energl' and Unilities Board) (C.A.), supra note 34 at paras. 13, 15. lbid. at paras. 16-19. 
8 on 13 July 1899 at Fort Chipewyan. The MCFN are also signatories to a 1986 settlement of a treaty land entitlement claim with the Governments of Alberta and Canada.

Fort Chipewyan, established as a fur trading post in 1788 and relocated to its present site in 1798, has a rich history and much has been written by historians and anthropologists about the roots of these two communities, their traditions, and the impacts of the developments over the last century on their culture and the exercise of their traditional ways of life. "17 Both the ACFN and the MCFN have long histories and associations with the fur trade in northeastern Alberta, and into Saskatchewan. Today, members of these communities continue to live in and around Fort Chipewyan as well as in other communities such as Fort McMurray.

In addition to ethnographic and historical sources that describe the traditional exercises of the MCFN and ACFN's treaty rights, the MCFN has been involved in recent litigation where the source and extent of their rights have been at issue. ${ }^{118}$

In Mikisew, the MCFN sought judicial review of a decision by the Minister of Canadian Heritage to approve construction of a winter road through Wood Buffalo National Park (WBNP). The MCFN was successful in the Federal Court Trial Division, establishing that it had treaty rights to hunt, fish, and trap in Wood Buffalo National Park, that those rights were infringed by the decision to build a road, and that they had not been adequately consulted. The decision was reversed on appeal, the majority concluding that no consultation was required because the lands had been "taken up" within the meaning of the government's rights to do so under Treaty 8 and, accordingly, that no "infringement" of MCFN rights had occurred that would trigger a duty to consult. At the time of writing this article, the appeal from the Federal Court of Appeal had been heard by the Supreme Court of Canada and judgment reserved.

Aside from the rulings with respect to the duty to consult, however, the Mikisew case provides some insights into the exercise by the MCFN of their treaty rights. Evidence was filed with respect to the history of the MCFN, trapping and hunting activity within the area that the road would traverse, and the potential impacts of the road on that activity. Evidence was also filed with respect to the 1986 settlement agreements of the MCFN's treaty land entitlement.

In her reasons, Hansen J. noted the following:

[8] First Nations people have inhabited WBNp for over 8,000 years. Today, subsistellec hunting. trapping and fishing and commercial trapping still take place within the Park. The Park was cstablished in 1922 to

117 Sec e.g., A.D. Fisher, "A Colonial Education System; Historical Changes and Schooling in Fort Chipewyan" (1981) 2 Canadian Journal of Anthropology 37; Patricia A. McCormack. "Romancing the Northwest as Prescriptive History: Fort Chipewyan and the Northern Fxpansion ol the Canadian State" in Patricia A. MeCormack \& R. GeolTrey Ironside, eds. The Uncovered Past: Roos of Northern Alberfo Socicties (Edmonton: Canadian Circumpolar Institute. 1993) 89; Phillip R. Coutu \& Lorrainc IloltimanMercredi, Inkonze: The Stonces of Traditional Knowledge: A Jistom of Northeastern Alberta (Fdmonton: Thundenwoman Ethnographics, 1999); Richard T. Price. "Contemporary Land Claims Negotiations and Settlement: The Political Challenge of Alberta's Fort Chipewyan Crec" in McCormack \& Ironside, ibid., 127.

Mfikisew, supra note 1. 
protect the last remaining herds of wood bison in northem Canada. Since 1949, resource harvesting within the Park has been governed by specilic game regulation.

[98] In my opinion. the upplicant has demonstrated the following impacts on its right to trap and hunt in WBNP:

\section{i) a geographical linitution}

Within the road corridor. Mikisew hunters will be prohibited by regulation from exercising their right to hunt. The ability to carry on traditional hunting activities in proximity to the reserve lands is important to the exercise of the hunting right. Further, trapping will also be disrupted. Many of the Mikisew traplines are located close to the existing right-of-way, presumably for case of access. In fact, the proposed route passes through Mikisew's designated registered trapping area and passes within one kilometre of a Mikisew trapping cabin. To the extent that traplines will have to be re-localed, Mikisew's right to trap is clearly impacted.

ii) potential adverse comomic comsegurences

First, the Draft Environmental Assessment Report states the road could potentially result in a diminuation in quantily of "catch" for Mikisew; fewer furhearers will be caught in their traps. Second, the same report identilies a potential change in the composition of the "catch"; the more lucrative or rare species of furbearers may decline in population.

\section{iii) potential culnural consequences}

Subsistence hunting and trapping hy traditional users of the Park's resources had been in decline for many years. Opening up this remote wilderness to velicle traffic could potentially exacerbate the challenges facing First Nations struggling to maintain their culture. For example, if the moose population is adversely alfected by increased poaching or predation pressures caused by the road, Mikisew will be forced to change their hunting strategies. This may simply be one more incentive to abandon a traditional lifestyle and turn to other modes of living. Further, Mikisew argues that keping the land around the reserve in its natural condition and maintaining their hunting and trapping traditions is important to their ability to pass their skills on to the next gencration of Mikisew. ${ }^{19}$

\section{SUMMARY}

Aboriginal risks are playing an increasingly important role in oil and gas development where Aboriginal and treaty rights exist or may exist. Traditionally, many industry participants, and often the Crown, have treated Aboriginal issues on a case-by-case basis, ignoring existing information that may be relevant in current decisions. A number of recent court decisions have indicated that, depending on the government action in question,

114 Mikisew 2001, supra note 3 at para. 98. Justice Sharlow, dissenting. reviewed these findings on appeal, Mikisew (C.A.), supra note 1 . The majority did not address these conclusions, having concluded that the land for the road was "taken up" within the meaning of Treaty 8 , and that there was no infringement of a treaty right that would require consultation within the meaning of the Sparrow' test. 
information that has previously been provided to government may be direclly relevant in determining both the existence and scope of the Crown's duty to First Nations. The materials set out above on both Treaty 8 and individual First Nations highlight publicly available information most, if not all, of which has been provided to government. Similar materials exist for many other First Nations. While each situation can only be determined on the specific facts of each case, the availability of these materials could be signilicant in determining the Aboriginal risks associated with a particular development.

Publicly available information can also be of assistance in conducting an Aboriginal risk assessment of a potential project or program. The results of such an assessment may have a direct bearing on the program or project in question or, at a minimum, assist in efforts to manage the Aboriginal risks associated with a given project, including efforts to ensure that the obligations of government to the First Nation are met.

To the extent that industry is delegated the responsibility for carrying out the procedural aspects of consultation, public information can play a significant role in the consultation and, if necessary, accommodation process. While neither the Crown nor industry can rely solely on publicly available information to fulfill the Crown's obligations to First Nations, this information can help inform the consultation process and can provide an indication of the type of information that is available regarding the First Nation in question. 